PESHAWAR JOURNAL OF PSYCHOLOGY AND BEHAVIORAL SCIENCES, 2017, VOL. 3, NO. 2, 135-143

\title{
Domestic Violence against Women in Union Council Watala, District Bhimber Azad Kashmir
}

\author{
Abdul Jabbar Raja ${ }^{1}$, Intikhab Alam² and \\ Saima Sarir ${ }^{3}$ \\ The University Agriculture Peshawar-Pakistan
}

The study conducted in union council Watala, distract Bhimber of Azad Kashmir to probe out domestic violence against women. The main objective of the study was to find out prevalence of domestic violence with reference to dowry. The data was collected from $\mathrm{N}=379$ respondents from three selected villages on proportionate sampling procedure. The data was analyzed by simple percentages and frequencies, while to see association between dowry and domestic violence chi-square statistics was used. The study found a significant and positive association of dowry is the root cause of domestic violence, women commit suicide as a solution to dowry related domestic violence, dowry causes economic problems for the family of bride, your family arranged your entire dowry easily, dowry is demanded by the groom family, dowry system helps bride to adjust in new family and total value of the dowry is very less than women's share in family property. Awareness campaign should be launched against dowry in the media, imams of mosques should focus on this issue in their Friday sermons, share in parent property inheritance should be given to women to enhance their status in the in laws are some of the suggestions on the basis of study findings.

Keywords: dowry, domestic violence, nature of violence

Domestic violence is a broad term which is also explained by many other similar terminologies. Their main theme was explained by Krug, Dahlberg, Mercy, Zwiand Lozano in 2002 is: "Creation of harm and

\footnotetext{
${ }^{1}$ Student, Department of Rural Sociology, The University of Agriculture Peshawar-Pakistan ${ }^{2}$ Lecturer, Department of Rural Sociology, The University of Agriculture Peshawar-Pakistan

${ }^{3}$ Lecturer, Department of Rural Sociology, The University of Agriculture Peshawar-Pakistan
} 
use of coercive force between intimate partners is called as domestic violence".

Domestic violence is a prevailing problem all over the world. It is present in all age groups, societies and socio economic levels (Pyles \& Postmus, 2004). No society is having domestic violence free system. It is present all over the world in different forms and at different levels. Generally domestic violence is illustrated as a problem that is family based and commonly taken as the offensive and coercive behavior which can cause emotional and psychological disorders, sexual compulsion, physical injuries and also financially controlling a person. Basically it is concerned with the mistreatment between intimate partners. The adults take steps of violence and abusive behaviors to control and dictate their close partners (Healey, Smith and O'Sullivan, 1998).

In South Asia, dowry is practiced very commonly. Much of the efforts are being made by the governments of these countries to uproot this problem, but it still exists and is practiced on a large scale (Davis, 2007). It is practiced as a duty and people do not realize the negative outcomes of this practice.

Women are being given their share in property as their right in Islam, but most of the people do not take it into consideration. They use dowry as an alternative way to grant women their share in property. Share of their property is half as compared to the share received by males. But in case of dowry they are given very less amount as compared to their share in property (Donnan, 1990; and Patel, 1999). Money and other households are given to a girl on her marriage in Pakistan. This is considered legal as it is thought that it will help her to start a new life after the marriage (Afzal, 1973).

This norm of the society has caused many problems for the poor people. People, who lack money and resources, have nothing to offer their females at marriage. This forces them to take loans or borrow money from others to give dowry. Hence they are trapped in a new circle of poverty and misery. In most of the cases women commit suicide due to these circumstances. Also in some cases the women are forced to kill their female baby, before birth or after the birth to avoid such circumstances later. Dowry causes many problems for women even after their marriage. A specific amount of money or demand of specific item/items is made by the family of the groom. If it is not fulfilled or partially fulfilled, many problems arise as a result. Many of the women face violence and bad behavior in new family due to less or no dowry. In some cases even death 
of such women was reported. Sometimes the women even get divorce at the end. This has caused a big problem in society and it demands special attention (Bhuiya, 2007).

Veena (2002) explained that in Pakistani society, dowry system is present and performed widely. Dowry is demanded by the groom family. People give dowry to their daughters in many forms. Dowry is given to the female members as money, household items etc. It helps them to start a new life with their partners. But sometimes they are not welcomed by the groom family when the bride brings no dowry or fewer dowries. It causes many problems for her.

Dekker and Hoogeven (2002) stated that in dowry practicing societies, the dowry given to females is taken as their share in family property. They are not given any other financial aid or share by their family. The value of dowry is less than the value of their share in property, many times. And this money or items given to them are given with the purpose of making the women strong financially so that this money could assist them in need in near future.

Heise et.al (1994) reported that dowry has caused many cases of domestic violence in Bangladesh. Sometimes these cases proved more brutal and acid was used as weapon against women. Acid was thrown on women saying that the dowry in not enough. Such types of cases have reached to an alarming state. Women are tortured for bringing less or even no dowry. The demand of dowry increases with each coming day, making women vulnerable to abuses, which are from poor families. Dowry has many victims of acid burning in Bangladesh. It is estimated that 200 acid burnings are due to dowry out of total acid burnings in Bangladesh. This shows the worst situation of domestic violence.

Ram (2000) found that the dowry system has adverse effects on families with low economy. Once a family goes for the marriage of their daughter or sister, they take loans from the other people or bank. It makes their economic conditions more badly and they are forced to live hand to mouth. It causes a lot of social problems. They may be attracted to crimes and other illegal means of earning money to pay the debts and regain the economic stability.

Rao (1993) explained that dowry is practiced worldwide. The dowry arrangement costs many times more than the income of a family. It happens in the cases of poor and middle class families that the income of a family is very less than the dowry arrangement cost and such families do not have the inheritance property. Even then they have to arrange the 
dowry for the marriages of their female members. This causes them to save money for dowry arrangement and even to borrow money. This ultimately causes them to get in debt cycle.

Kumari (1989) found the behavior of the women, who were abused due to dowry. It showed very alarming results. Due to the domestic violence caused due to dowry, a great number of women accepted suicide as a solution. $1 / 4$ women, abused due to dowry, taken suicide as a solution to violence. Most of the women killed themselves as well as the children. This shows the dire situation due to domestic violence. Women find no way to escape from the cycle of the violence; ultimately they end it by killing themselves.

\section{Method and Procedure}

The study was carried out in Union council Watala, District Bhimber, Azad Kashmir. Women from different age groups, educational backgrounds and different socio-economic status were selected. Total population of potential respondents with said characteristics came out to be 27000. Sekaran (2003) simplified the sample size decision process, for multiple variables, by providing a table that greatly simplify the decision of sample size and ensure good decision model. For a population size of 27000 a sample size of 379 respondents was selected through criterion devised by Sekaran (2003). A conceptual framework was devised as shown in the Table 1 and questions were asked accordingly from the respondents devised through Likert scale. The dependent variable (domestic violence against women) was indexed and cross tabulated with independent variable (dowry) to measure the association. Chi-square test outlined by Tai (1978) at bi-variate level was used through the formula as below

$$
\mathrm{x}^{2}=\sum_{j=1}^{j} \sum_{j=1}^{k} \frac{(\mathrm{oij}-\mathrm{e} i j)^{2}}{\mathrm{eij}}
$$

Table 1.

Conceptual Framework

Independent variable Dependent Variable

Dowry

Domestic violence against women

PESHAWAR JOURNAL OF PSYCHOLOGY AND BEHAVIORAL SCIENCES, 2017, VOL. 3, NO. 2, 135-143 


\section{Result and Discussion}

\section{Frequency and percentage distributions regarding dowry}

Certain statements attributing domestic violence against women with association to dowry were asked as shown in Table-2. Table shows that majority $95.3 \%$ respondent reported that Dowry was the root cause of domestic violence in the study area. These results are similar to the findings of Davis (2007), that dowry is the root cause of domestic violence in south Asian countries. Furthermore, 92.3\% respondents mentioned that the total value of the dowry was very less than women's share in family property. These results are in line with the Donnan (1988) and Patel (1979) that women are given dowry as the alternative of their share in property. And this amount which is used to arrange dowry is very less than the actual share of women in family property. In addition, $89.7 \%$ respondents disclosed that dowry was demanded by the groom family. These findings are synonymous to the research results of Bhuiya (1999) that a specific demand is made by the groom family for dowry. This demand may be of specific items or a certain amount of money. Majority $86.8 \%$ respondent told that dowry system helps bride to adjust in new family. These finding are alike to that of Afzal (1973). Moreover, 86.0\% respondents replied that dowry causes economic problems for the family of bride. These findings are synonymous with the conclusions of Khalid (2008); Ram (1993); Rao (1993) and Paras (1987) that the dowry arrangement very badly affects the economy of a family. Dowry arrangement exerts enormous economic burden and financial pressure on the family members of the bride. In addition, 50.7\% respondents reported that Women commit suicide as a solution to dowry related domestic violence. These results are similar to the research findings of Kumari (1989) that women facing domestic violence which lead to commit suicide as the final solution to end this process. In some cases such women killed their children too before committing suicide. 
Table 2

Frequency and Percentage Distributions of Responses Regarding Dowry and Domestic Violence Against Women

\begin{tabular}{|c|c|c|c|c|}
\hline Questions & Agree & Disagree & Don't & Total \\
\hline $\begin{array}{l}\text { Dowry is the root cause of domestic } \\
\text { violence. }\end{array}$ & $361(95.3)$ & $17(4.5)$ & $1(0.3)$ & $379(100)$ \\
\hline $\begin{array}{l}\text { Women commit suicide as a solution } \\
\text { to dowry related domestic violence. }\end{array}$ & $192(50.7)$ & $103(27.2)$ & $84(22.2)$ & $379(100)$ \\
\hline $\begin{array}{l}\text { Dowry causes economic problems for } \\
\text { the family of bride. }\end{array}$ & $326(86.0)$ & $36(9.5)$ & $17(4.5)$ & $379(100)$ \\
\hline $\begin{array}{l}\text { Your family arranged your entire } \\
\text { dowry easily. }\end{array}$ & $3(0.7)$ & $200(52.7)$ & $176(46.4)$ & $379(100)$ \\
\hline $\begin{array}{l}\text { Dowry is demanded by the groom } \\
\text { family. }\end{array}$ & $340(89.7)$ & $23(6.1)$ & $16(4.2)$ & $379(100)$ \\
\hline $\begin{array}{l}\text { Dowry system helps bride to adjust in } \\
\text { new family. }\end{array}$ & $329(86.8)$ & $46(12.1)$ & $4(1.05)$ & $379(100)$ \\
\hline $\begin{array}{l}\text { Total value of the dowry is very less } \\
\text { than women's share in family } \\
\text { property. }\end{array}$ & $350(92.3)$ & $12(3.3)$ & $17(4.5)$ & $379(100)$ \\
\hline
\end{tabular}

Note: Number in table represent frequencies and number in parenthesis represent percentage proportion of respondents.

\section{Association between dowry and domestic violence}

Dowry is the root cause of domestic violence was found highly significant $(\mathrm{p}<0.001)$ with domestic violence against women. These findings are similar with (Davis, 2007) that dowry is practiced commonly in South Asia countries at large scale. Moreover, Women commit suicide as a solution to dowry related domestic violence was found highly significant $(\mathrm{p}<0.001)$ with domestic violence against women. These results have resemblance with findings of (Khalid,2008) that most of the cases in which women commit suicide due to dowry related problems. Furthermore, Dowry causes economic problems for the family of bride was found highly significant $(p<0.001)$ with domestic violence against women. These findings are synonymous with the conclusion of (Rao, 1993;Ram,1993) that dowry system has adverse effects on families with low economy such as living hand to mouth, committing crimes and fraud at work place. In addition, family arranged your entire dowry easily was found highly significant $(\mathrm{p}<0.001)$ with domestic violence against women. These results are in line with (Paras,1987) that dowry arrangement forces family members to earn from just or unjust means. Dowry was demanded by the groom family was found highly significant $(p<0.001)$ with domestic 
violence against women. These are findings are similar with (Veena,2002; Bhuiya, 1999 and Heise et. al,1994) that bride without dowry is exposes to many problems such as bad behavior by in laws, sometimes these cases proved more brutal in nature domestic violence, acid burning, divorce and even death. Dowry system helps bride to adjust in new family was found highly significant $(\mathrm{p}<0.001)$ with domestic violence against women. These results matched with (Veena, 2002; Dekker and Hoogeven,2002) that dowry help women to start a new life with their partner. Dowry is given to women with the purpose of making them strong financially. Moreover, total value of the dowry is very less than women's share in family property was found highly significant $(\mathrm{p}<0.001)$ with domestic violence against women. These findings are line with (Dekker and Hoogeven, 2002) that dowry is taken as share of the female in the family property. Value of dowry is many times less than their share in family property.

Table 3

Association Between Dowry and Domestic Violence Against Women

\begin{tabular}{|c|c|c|c|c|}
\hline Statement & Yes & No & Uncertain & p.value \\
\hline \multicolumn{5}{|c|}{ Dowry is the root cause of domestic violence. } \\
\hline Yes & $291(76.8 \%)$ & $70(18.5 \%)$ & $0(0.0 \%)$ & \multirow{3}{*}{$\begin{array}{c}x^{2}=250.24 \\
\mathrm{p}<0.001\end{array}$} \\
\hline No & $0(0.0 \%)$ & $6(1.6 \%)$ & $11(2.9 \%)$ & \\
\hline Uncertain & $1(0.3 \%)$ & $0(0.0 \%)$ & $0(0.0 \%)$ & \\
\hline \multicolumn{5}{|c|}{ Women commit suicide as a solution to dowry related domestic violence. } \\
\hline Yes & $176(46.4 \%)$ & $16(4.2 \%)$ & $0(0.0 \%)$ & \multirow{3}{*}{$\begin{array}{c}x^{2}=178.12^{a} \\
\mathrm{p}<0.001\end{array}$} \\
\hline No & $96(25.3 \%)$ & $7(1.8 \%)$ & $0(0.0 \%)$ & \\
\hline Uncertain & $20(5.3 \%)$ & $53(14 \%)$ & $11(2.9 \%)$ & \\
\hline \multicolumn{5}{|c|}{ Dowry causes economic problems for the family of bride. } \\
\hline Yes & $292(77 \%)$ & $34(9 \%)$ & $0(0.0 \%)$ & \multirow{3}{*}{$\begin{array}{c}x^{2}=413.47 \\
\mathrm{p}<0.001\end{array}$} \\
\hline No & $0(0.0 \%)$ & $36(9.5 \% \%)$ & $0(0.0 \%)$ & \\
\hline Uncertain & $0(0 \%)$ & $6(1.6 \%)$ & $11(2.9 \%)$ & \\
\hline \multicolumn{5}{|c|}{ Your family arranged your entire dowry easily. } \\
\hline Yes & $0(0.0 \%)$ & $0(0.0 \%)$ & $0(0.0 \%)$ & \multirow{3}{*}{$\begin{array}{c}x^{2}=57.87 \\
\mathrm{p}<.001\end{array}$} \\
\hline No & $187(49.3 \%)$ & $16(4.2 \%)$ & $0(0.0 \%)$ & \\
\hline Uncertain & $105(27.7 \%)$ & $60(25.8 \%)$ & $11(2.9 \%)$ & \\
\hline \multicolumn{5}{|c|}{ Dowry is demanded by the groom family. } \\
\hline Yes & $292(77 \%)$ & $48(12.7 \%)$ & $0(0.0 \%)$ & \multirow{3}{*}{$\begin{array}{c}x^{2}=363.33 \\
\mathrm{p}<.001\end{array}$} \\
\hline No & $0(0.0 \%)$ & $23(6.1 \%)$ & $0(0.0 \%)$ & \\
\hline Uncertain & $0(0.0 \%)$ & $5(1.3 \%)$ & $11(2.9 \%)$ & \\
\hline \multicolumn{5}{|c|}{ Dowry system helps bride to adjust in new family. } \\
\hline Yes & $292(77 \%)$ & $37(9.8 \%)$ & $0(\%)$ & \multirow{3}{*}{$\begin{array}{c}x^{2}=312.20 \\
\mathrm{p}<.001\end{array}$} \\
\hline No & $0(0.0 \%)$ & $39(10.3 \%)$ & $11(2.9 \%)$ & \\
\hline Uncertain & $0(0.0 \%)$ & $0(0.0 \%)$ & $0(0.0 \%)$ & \\
\hline
\end{tabular}


Total value of the dowry is very less than women's share in family property.

\begin{tabular}{lcccc} 
Yes & $291(76.8 \%)$ & $59(15.6 \%)$ & $0(0.0 \%)$ & \\
No & $1(0.3 \%)$ & $16(4.2 \%)$ & $0(0.0 \%)$ & $x^{2}=407.63$ \\
Uncertain & $0(0.0 \%)$ & $1(0.3 \%)$ & $11(2.9 \%)$ & $\mathrm{p}<.001$ \\
\hline
\end{tabular}

\section{Conclusion and Recommendations:}

The study concluded that dowry was the root cause of domestic violence in the study area; The total value of the dowry was very less than women's share in family property which means that women were given dowry as the alternative of their share in property, this amount which was used to arrange dowry was very less than the actual share of women in family property. In addition, dowry was demanded by the groom family. Dowry crushed the women. The dowry arrangement very badly affected the economy of a family. Awareness campaign should be launched against dowry in the media, and Imams of mosques should focus on this issue in their Friday sermons, share in parent property inheritance should be given to women to enhance their status in the in laws are some of the suggestions on the basis of study findings.

\section{References}

Afzal, M., Bean, L. L., \& Husain, I. (1973). Muslim marriages: age, mehr, and social status. The Pakistan Development Review, 12(1), 48-61.

Dekker, M., \& Hoogeveen, H. (2002). Bride wealth and household security in rural Zimbabwe. Journal of African Economies, 11(1), 114-145.

Donnan, H. (1990). Mixed marriage in comparative perspective: gender and power in Northern Ireland and Pakistan. Journal of comparative family studies, 207-225.

Eaton, D. K., Davis, K. S., Barrios, L., Brener, N. D., \& Noonan, R. K. (2007). Associations of dating violence victimization with lifetime participation, co-occurrence, and early initiation of risk behaviors among US high school students. Journal of interpersonal violence, 22(5), 585-602.

Healey, K. M., \& Smith, C. O' Sullivan (1998). Batterer intervention: Program approaches and criminal justice strategies.

Heise, L. (1994). Gender-based abuse: the global epidemic. Cadernos de Saúde Pública, 10, S135-S145. 
Iqbal, H., Afzal, S., \& Inayat, M. (2012). Gender Discrimination: Implications for Pakistan Security. IOSR Journal of Humanities and Social Science, 1(4), 16-25.

Krug, E. G., Mercy, J. A., Dahlberg, L. L., \&Zwi, A. B. (2002). The world report on violence and health. The lancet, 360(9339), 1083-1088.

Kumari, R. (1989). Brides are not for burning: Dowry victims in India. Sangam.

Oldenburg, V. T. (2002). Dowry murder: The imperial origins of a cultural crime. Oxford University Press on Demand.

Patel, V., Araya, R., de Lima, M., Ludermir, A., \& Todd, C. (1999). Women, poverty and common mental disorders in four restructuring societies. Social science \& medicine, 49 (11), 1461-1471.

Pyles, L., \& Postmus, J. L. (2004). Addressing the problem of domestic violence: How far have we come?. Affilia, 19(4), 376-388.

Ram, K. (2000). Instabilities in the discourse of 'rights' in India. Human rights and gender politics: Asia-Pacific perspectives, 60-82.

Rao, V. (1993). The rising price of husbands: A hedonic analysis of dowry increases in rural India. Journal of political Economy, 666-677.

Wahed, T., \& Bhuiya, A. (2007). Battered bodies \& shattered minds: Violence against women in Bangladesh. Indian Journal of Medical Research, 126(4), 341. 